
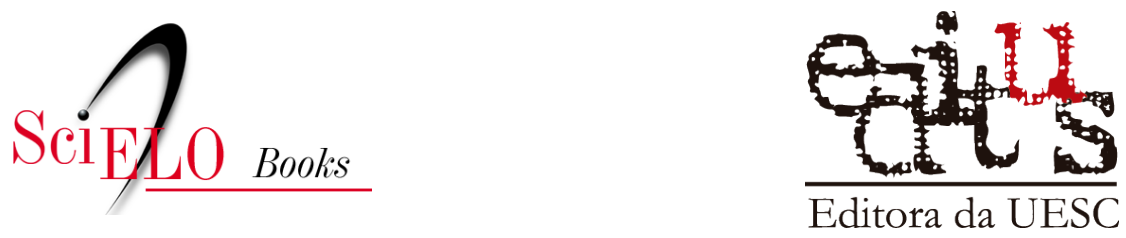

\title{
5 Pesquisa de campo: dando voz às crianças de Candomblé
}

\author{
Ademar Cirne
}

\section{SciELO Books / SciELO Livros / SciELO Libros}

CIRNE, A. Pesquisa de campo: dando voz às crianças de Candomblé. In: Racismo religioso em escolas da Bahia: autoafirmação e inclusão de crianças e jovens de terreiro [online]. Ilhéus, BA: Editus, 2020, pp. 131-169. Transfluência series. ISBN: 978-65-86213-16-4. https://doi.org/10.7476/9786586213294.0006.

\section{(c) $\underset{\mathrm{EY}}{ }$}

All the contents of this work, except where otherwise noted, is licensed under a Creative Commons Attribution 4.0 International license.

Todo o conteúdo deste trabalho, exceto quando houver ressalva, é publicado sob a licença Creative Commons Atribição 4.0.

Todo el contenido de esta obra, excepto donde se indique lo contrario, está bajo licencia de la licencia Creative Commons Reconocimento 4.0. 


\section{Pesquisa de campo: dando voz às crianças de Candomblé}

A partir das leituras realizadas para construção desta obra, considera-se que os postulados do multiculturalismo crítico, defendidos principalmente pelo autor McLaren (1997), são os que podem melhor embasar esta pesquisa. Esse modelo de investigação possibilita a observação a partir de uma pedagogia de resistência, inquirindo os sistemas culturais preestabelecidos.

Entender multiculturalismo e educação pressupõe analisar concepções e práticas pedagógicas baseadas em um movimento teórico que nasceu a partir da segunda metade do século XIX, nos Estados Unidos, e que se difundiu pelo mundo ocidental como forma de enfrentamento dos conflitos surgidos por conta de questões econômicas, políticas, étnico-raciais e culturais na luta para combater discriminações e preconceitos, haja vista as dificuldades de grupos e indivíduos de acolher e conviver com a pluralidade e as diferenças. O relato de McLaren (2000, p. 86-87), expresso no texto a seguir, apresenta de que forma a educação feita 
com base nos princípios do multiculturalismo crítico pode levar à construção de uma sociedade mais justa e igualitária, tanto no aspecto moral quanto material capitalista.

O pós-modernismo de resistência oferece aos educadores que estão trabalhando com educação multicultural uma maneira de interrogar a localidade, o posicionamento e a especificidade do conhecimento (em termos de localização de raça, classe e gênero dos alunos e alunas) e de gerar pluralidade de verdades (em vez de uma verdade apodítica construída em torno da norma invisível do eurocentrismo e da etnicidade branca). Ao mesmo tempo, esta perspectiva também situa a construção do significado em termos dos interesses materiais que estão operando na produção de efeitos de verdade - isto é, na produção de formas de inteligibilidade e de práticas sociais. Consequentemente, educadoras que trabalham com a perspectiva de um pós-modernismo de resistência tornam-se capazes de questionar as assunções políticas e as relações de determinação sobre as quais as verdades sociais estão fundamentadas, tanto nas comunidades onde elas trabalham quanto na sociedade maior da qual elas fazem parte.

O conceito do multiculturalismo acaba ganhando mais visibilidade, principalmente nos países americanos, a partir do momento do crescimento e expansão do sistema capitalista que se torna cada vez mais global.

Economicamente, o novo modelo é representado pela chamada globalização econômica, que significa a internacionalização do capital, tendo como base a produção, distribuição e consumo de bens e serviços, organizados por meio de uma estratégia mundial na intenção de promover uma padronização dos gostos dos consumidores de todos os lugares do mundo, de uma forma muito agressiva sobre as identidades culturais diversas, visto que a globalização 
pode significar homogeneizar, diluindo identidades, destruindo marcas do que os colonizadores chamam de culturas inferiores. Para Siqueira e Pereira (2002 apud MORANTE; GASPARIN, 2010, p. 3),

\begin{abstract}
[...] a sociedade moderna, tipicamente industrial, [...] sofreu uma transformação radical, sendo caracterizada hoje como uma sociedade globalizada, impulsionada pela explosão das informações e intensificação das comunicações em nível mundial. Este cenário já não pode ser ignorado pela educação, pois o impacto desses processos no cotidiano escolar é cada vez maior. A problemática atual das escolas, principalmente nas grandes cidades, local onde se multiplicam tensões e conflitos já não pode ser reduzida aos aspectos relativos à estruturação interna da cultura escolar, necessita ser repensada para incorporar na sua própria concepção estas realidades sociais e culturais.
\end{abstract}

A partir de tantas tensões e desafios originários da globalização, que contribui decisivamente para aprofundar a complexidade da questão da centralidade da cultura, enxergamos os princípios do multiculturalismo crítico do teórico Mc Laren (1997). Eles possuem condições para explicar e ajudar na construção de uma escola de maior respeito às diversidades, principalmente culturais e religiosas.

O multiculturalismo não é somente um movimento social em defesa das minorias negras, mas também incorpora-se em uma abordagem curricular contrária a toda forma de preconceito no espaço escolar. Conforme afirmam Silva e Brandim (2008, p. 56), o multiculturalismo

Inicialmente, constitui-se desvinculado dos sistemas de ensino, incorporado na sua maioria pelos movimentos sociais, 
especialmente os grupos sociais negros. O eixo orientador do movimento é o combate ao racismo e a luta por direitos civis, Gonçalves e Silvia (1998) situam o início do movimento no final do século XIX, com as lutas dos afrodescendentes, que buscavam a igualdade de exercício dos direitos civis e o combate à discriminação racial no país.

Observando o pensamento inicial multiculturalista, percebemos que podemos relacioná-lo com as ideias de educadores brasileiros, principalmente com a professora Nilma Lino Gomes, que em seus escritos propõe um modelo de currículo que possa iniciar um processo de decolonização do Ensino Básico e Superior no Brasil, em oposição ao atual modelo curricular ainda frequente nas escolas brasileiras, que reitera o caráter colonizador eurocêntrico. Neste mesma linha Silva e Brandim (2008, p. 60) defendem o multiculturalista como instrumento para construção de uma diversidade cultural capaz de construir uma educação cidadã e inclusiva:

Para começar, o multiculturalismo é uma estratégia política de reconhecimento e representação da diversidade cultural, não podendo ser concebido dissociado dos contextos das lutas dos grupos culturalmente oprimidos. Politicamente, o movimento reflete sobre a necessidade de redefinir conceitos como cidadania e democracia, relacionando-os à afirmação e à representação política das identidades culturais subordinadas. Como corpo teórico questiona os conhecimentos produzidos e transmitidos pelas instituições escolares, evidenciando etnocentrismo e estereótipos criados pelos grupos sociais dominantes, silenciadores de outras visões de mundo. Busca, ainda, construir e conquistar espaços para que essas vozes se manifestem, recuperando histórias e desafiando a lógica dos discursos culturais hegemônicos. Os estudos sobre os fenômenos culturais partem da necessidade de 
compreensão dos mecanismos de poder que regulam e autorizam certos discursos e a outros não, contribuindo para fortalecer certas identidades culturais em detrimento de outras.

A grande meta do pensamento multiculturalista a ser atingida é a equidade, com base no acesso e permanência escolar de todas as crianças e jovens, independentemente das diferenças étnicas, sexuais, religiosas. Além disso, visa preparar todos para uma convivência plural e diversa.

Sendo assim, os procedimentos de pesquisa utilizados têm uma dupla função: a de permitir a análise e compreensão do problema enunciado e, ao mesmo tempo, contribuir para o processo de resistência dos Povos de Santo. As áreas da pesquisa foram a cidade de Itabuna, focalizando o Terreiro Ilê Axé Odara, na região Sul do estado da Bahia, e a cidade de Salvador, capital da Bahia, no Terreiro llê Axé Oxumarê.

As técnicas utilizadas na pesquisa foram levantamentos em fontes secundárias e outras de caráter primário, que contemplaram a pesquisa documental e pesquisa direta aplicada nos terreiros de Candomblé, principalmente com as crianças e jovens, mas também com seus pais, com as autoridades religiosas dos espaços pesquisados, além de observações na rede de educação formal. A seguir, apresenta-se o Quadro 1, que contém a síntese das técnicas com suas respectivas fontes de consulta utilizadas na pesquisa.

A construção desta obra consistiu em uma pesquisa qualitativa, por meio da elaboração de entrevista, com roteiro estruturado, aplicada diretamente pelo pesquisador, direcionada às crianças e jovens dos Terreiros, como também a outras pessoas da Casa (Babalorixá, Egbomes, 
Quadro 1. Síntese das técnicas, fontes e instrumentos utilizados na pesquisa.

\begin{tabular}{|l|l|}
\hline TÉCNICAS & FONTES \\
\hline $\begin{array}{l}\text { PRIMÁRIAS } \\
\text { Pesquisa direta. }\end{array}$ & $\begin{array}{l}\text { Observação de participante. } \\
\text { Entrevistas com crianças e jovens dos } \\
\text { Terreiros. Autoridades religiosas dos } \\
\text { Terreiros. }\end{array}$ \\
\hline $\begin{array}{l}\text { SECUNDÁRIAS } \\
\text { e iconográficas. }\end{array}$ & $\begin{array}{l}\text { Pais dos entrevistados. } \\
\text { Publicações: livros, artigos }\end{array}$ \\
\hline acadêmicos, matérias jornalísticas. \\
& Internet. \\
& $\begin{array}{l}\text { Imagens: fotos, cartazes. } \\
\text { Vídeos: filmes, documentários, } \\
\text { entrevistas. Dissertações de } \\
\text { mestrado. }\end{array}$ \\
\hline
\end{tabular}

Fonte: Elaboração própria. 
Ogãs e Ekedes). Além desta pesquisa direta nessas fontes primárias, utilizamos outras fontes, tais como: documentos do acervo das instituições religiosas pesquisadas, notícias de periódicos, jornais, documentos governamentais voltados para a Política de Promoção da Igualdade Racial e atas de reuniões do Coletivo de Entidades Negras, onde as pautas foram voltadas para as questões do racismo religioso.

Foram também realizadas as observações dos participantes sobre o comportamento das crianças e jovens entrevistados durante sua estadia no Terreiro, tanto no dia a dia, como nos dias de celebração religiosa. As informações foram registradas de forma organizada, desde o início da pesquisa, classificadas e tratadas qualitativamente por meio de descrição e análise do conteúdo dos fenômenos observados pelo autor nas várias fontes já definidas, de acordo com as questões e objetivos do estudo, assim como com o referencial teórico-metodológico adotado.

Espera-se, dessa maneira, que esta obra contribua para o fortalecimento da autoestima e, também, que possibilite aos jovens assumirem suas condições de religiosos de matriz africana na sociedade em geral e no ambiente escolar, em particular, superando as adversidades que se apresentam.

Em seguida, serão detalhadas as entrevistas realizadas nos dois terreiros escolhidos, com as crianças e jovens e o Sacerdote de cada Terreiro. 


\subsection{TERREIROS ILÊ AXÉ ODARA E ILÊ AXÉ OXUMARÊ}

A pesquisa direta ocorreu principalmente por meio de observações e de questionários realizados nos Terreiros selecionados, sendo um no município de Itabuna, Ilê Axé Odara, e outro em Salvador, llê Axé Oxumarê, conforme já mencionado. A escolha do primeiro local se justifica por estar situado na região Sul da Bahia, em Itabuna, onde está localizada a UFSB. A orientação inicial foi que este autor mantivesse o foco dos estudos no mesmo território em que cursou os componentes curriculares, para facilitar seu trabalho. O outro espaço religioso escolhido, em Salvador, foi em função de ser já frequentado pelo pesquisador desde o ano de 2007, como relatado no capítulo 4 desta obra.

A parte da pesquisa relacionada às fontes orais de investigação teve início na cidade de Itabuna, região Sul do estado da Bahia, que está localizada a cerca de 426 quilômetros de distância da capital da Bahia, ou a 333 quilômetros via ferry boat. Possui área total de $432.244 \mathrm{~km}^{2}$ e é o quinto município mais populoso da Bahia, e no Nordeste brasileiro ocupa o décimo lugar. Sua população, conforme estimativas do IBGE de 2018, alcançou 212.740 habitantes (IBGE, 2018).

Esse Terreiro pesquisado está localizado atualmente na Rua José Alves Franco, n. ${ }^{\circ} 1355$, Bairro São Roque, área periférica e popular da cidade. O llê Axé Odara, Casa de Candomblé da nação Angola, tem como seu líder espiritual (Babalorixá) Pai Gildo de Kaulange (Obaluayê). A origem da Casa se deu há cerca de 40 anos, inicialmente no Bairro de Fátima, próximo à localização atual do llê. O Terreiro consiste em uma instituição religiosa e social, sem fins lucrativos que, além das atividades sagradas de religião de matriz 
africana, utiliza o espaço para outras atividades culturais, como a prática da capoeira, maculelê, samba de roda, realização de curso de formação e profissionalização de costura e bordado, oficinas de cabelos crespos e de fabricação de instrumentos, como atabaques e agogôs.

As fotos abaixo (Figuras 18 e 19) apresentam o Barracão do Terreiro, local onde são realizadas as cerimônias públicas para homenagear os Orixás.

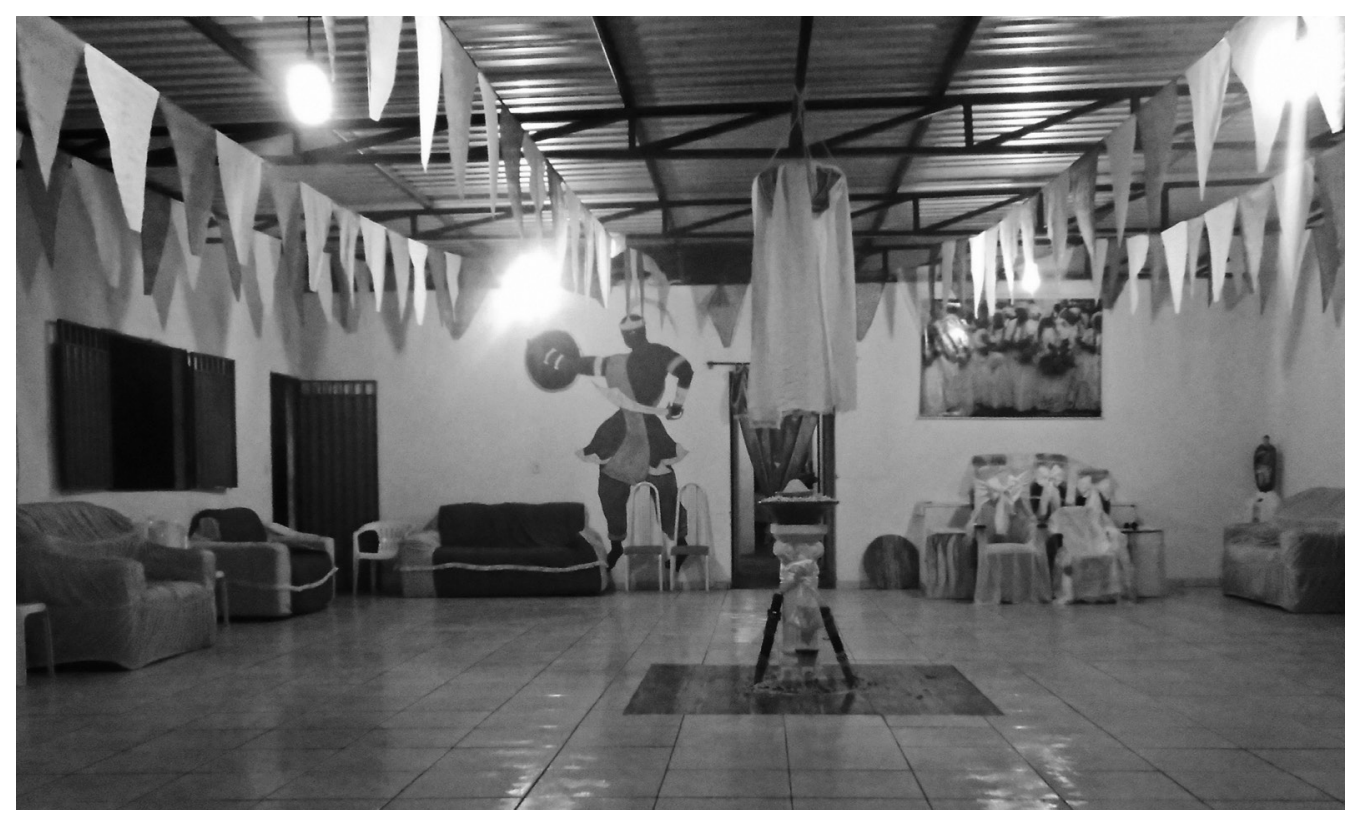

Fonte: Dados do pesquisador.

Figura 18

llê Axé Odara. 


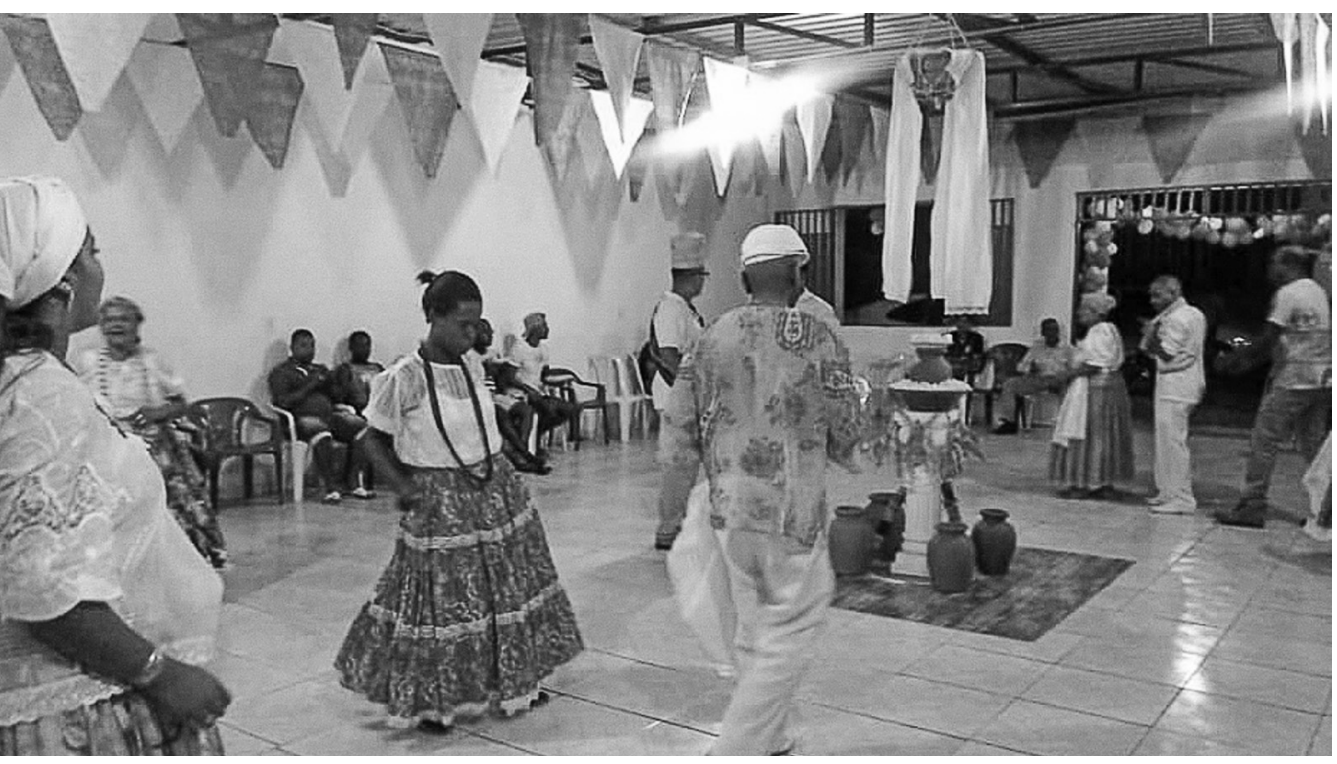

Fonte: Dados do autor

Figura 19

Ilê Axé Odara em

festa.

Conforme visto anteriormente, a segunda instituição religiosa escolhida para participar da pesquisa oral, a Casa de Oxumarê, é o Terreiro que o autor frequenta e tem o cargo de Ogã suspenso para o Orixá Yemanjá. Esta Casa situa-se na Avenida Vasco da Gama, n. 343, bairro Federação, na cidade de Salvador, Bahia.

A cidade de Salvador, primeira capital do Império Português no Brasil, foi fundada em 1549 pelo primeiro governador geral do Brasil, Tomé de Souza. Localizada inicialmente na Baía de Todos os Santos, foi construída de forma estratégica, aproveitando sua estrutura geográfica, assim, foi dividida em duas partes, uma baixa, voltada para as atividades comerciais, e uma alta, local da administração municipal e de defesa. 


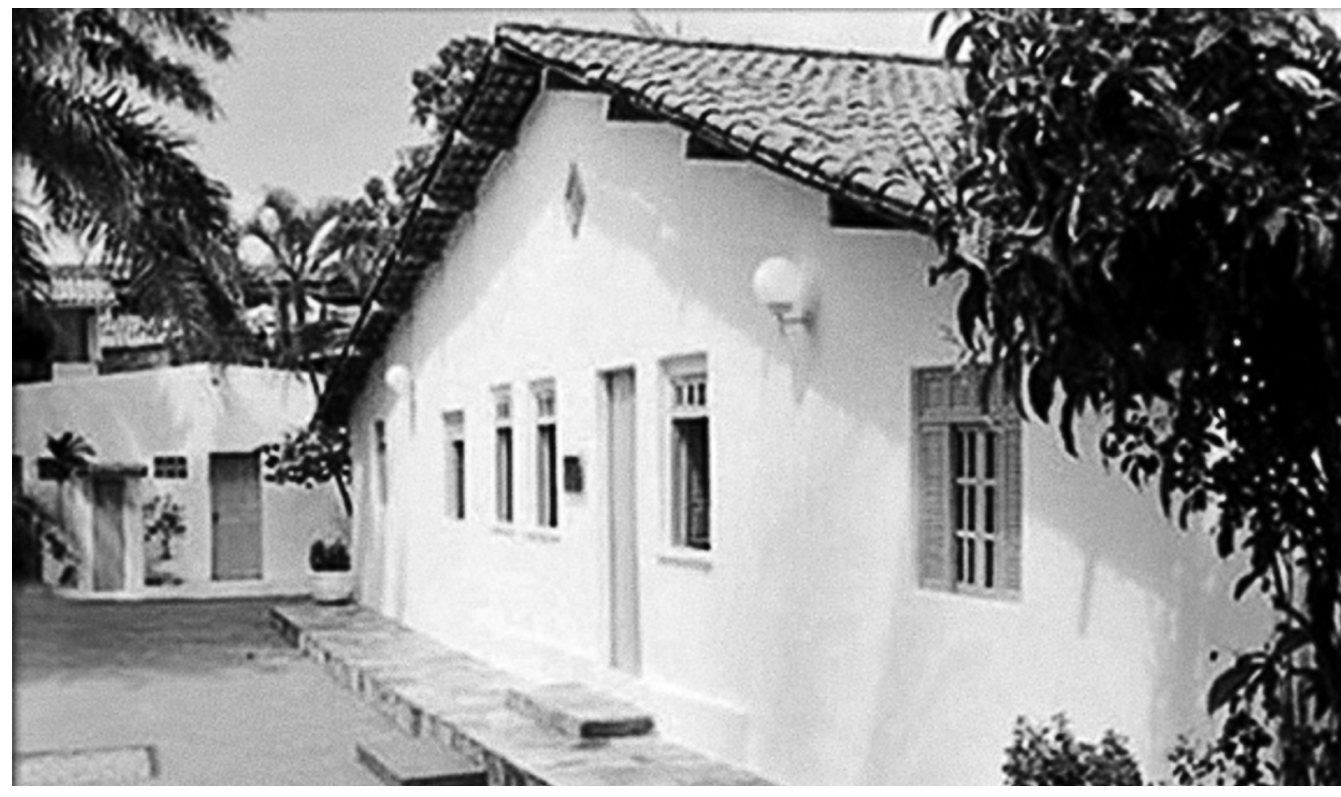

Fonte: Site llê Axé Oxumarê, s.d

Com o passar do tempo, a cidade avançava na direFigura 20

Fachada da Casa de Oxumarê.

ção norte, ocupando áreas do centro histórico, e na direção sul, tomando as regiões de vales onde surgiram grandes fazendas, que com seus desmembramentos foram formando regiões periféricas e ocupadas por uma população simples e de maioria negra. Uma das regiões formadas foi a antiga Estrada Dois de julho, hoje Avenida Vasco da Gama, onde há cerca de 180 anos nasceu a Casa de Oxumarê (Figuras 20 e 21), um dos terreiros mais antigos da cidade, atualmente liderado pelo Babalorixá Babá Pecê.

Vale lembrar que o terreiro de Candomblé, no momento do seu nascimento, precisava estar localizado distante do centro da cidade, pois era preciso fugir da forte 


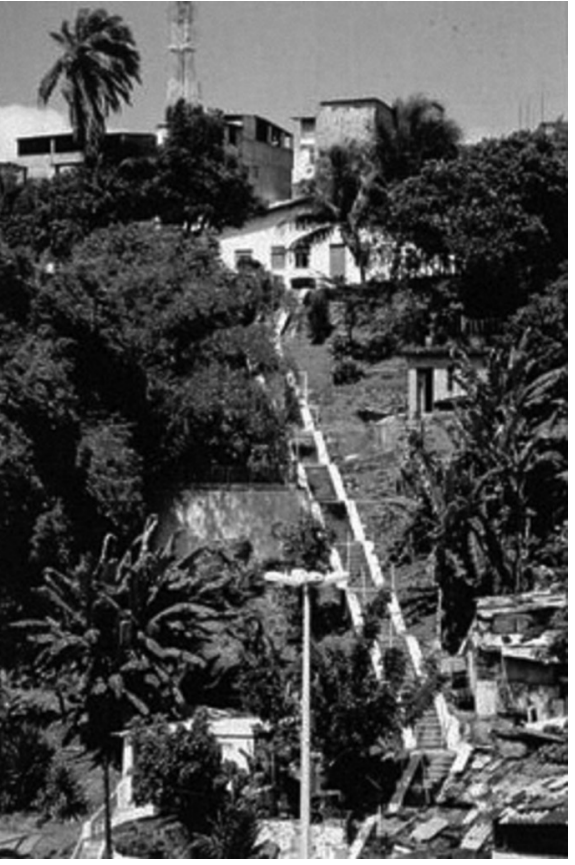

Fonte: Site llê Axé Oxumarê, s.d

Figura 21

Casa de Oxumarê.

perseguição das autoridades policiais que não permitia a realização de cerimônias religiosas desse tipo.

A história da Casa de Òsùmàrè remete à época da formação do candomblé no Brasil. A sua origem remonta ao início do século XIX e foi marcada pela luta e resistência de africanos escravizados que, obrigados a abandonarem suas terras e laços familiares, não renunciaram à sua cultura e fé. Seu fundador Bàbá Tàlábí, oriundo da antiga cidade Kpeyin Vedji, localizada a noroeste de Abomey, aportou em Salvador em 1795 na condição de escravizado. Foi um sacerdote com grande propriedade para introduzir e difundir o culto aos Òrìsà no Brasil, por pertencer a uma das mais relevantes famílias de Culto à Sakpata (Ajunsún), na África. Após curar seu senhor através da ciência Yorùbá, passa a viver como liberto e se dedica ao comércio iniciando trocas entre a capital e o recôncavo baiano. Por volta de 1820, na Cidade de Cachoeira, Bàbá Tàlábí ajuda a fundar o culto a Ajunsún no calundu do Obi Tedó ("fundação da família"). Este local tornar-se-ia a referência primordial da Casa de Òsùmàrè no Brasil (2012). 
5.2 ENTREVISTAS: SACERDOTES E CRIANÇAS E JOVENS DOS TERREIROS

Inicialmente, foram realizadas consultas aos Babalorixás dos Terreiros escolhidos, já mencionados acima, para confirmar o interesse e conveniência em participarem da pesquisa e autorizarem, formalmente, as entrevistas com as crianças e jovens das Casas. Foram assinados, como é recomendado pelas convenções acadêmicas, os Termos de Concordância.

Após os acordos estabelecidos, foram realizadas as entrevistas com cada um dos Pais de Santo. Passa-se a apresentar, a seguir, o resultado destas entrevistas realizadas com os Sacerdotes: Pai Gildo de Obaluayê, do Terreiro llê Axé Odara, em Itabuna, e Babalorixá Pecê de Oxumarê, do Terreiro de Oxumarê, em Salvador.

\subsubsection{SACERDOTES}

\section{PAI GILDO - ITABUNA (Figura 22)}

Na conversa inicial, Pai Gildo fez questão de contar como chegou ao Candomblé, o que se deu de forma muito difícil, visto que, apesar de já sentir a necessidade de seguir o caminho religioso, somente depois de uma séria doença que inicialmente lhe fez perder 27 quilos e abrir o corpo todo em feridas, além dos médicos o desenganarem, buscou solução do problema no Candomblé. Após passar por vários terreiros, sem solução, chegou na casa de uma senhora iniciada 


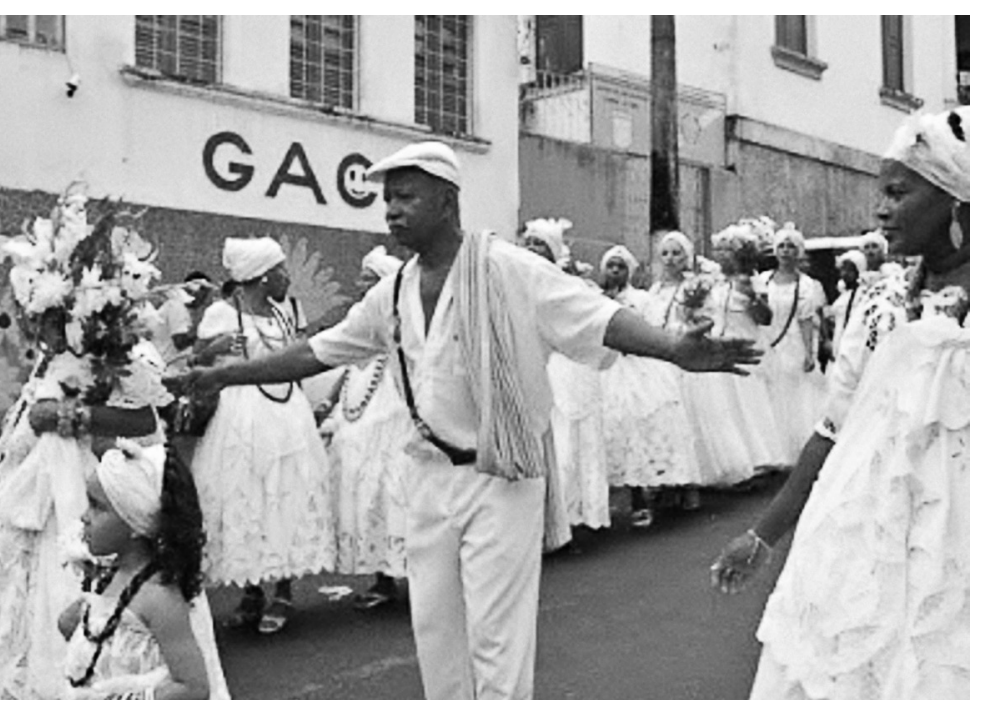

Fonte: Jornal Bahia Já, 2016

Figura 22

Pai Gildo na Lavagem do Beco do Fuxico. ao Orixá Nanã, que cuidou dele, levando a sua cura e a sua iniciação no Candomblé da nação Angola.

Após todo esse sofrimento, Pai Gildo entendeu que só construindo "esta obra religiosa" teria saúde. As principais atividades, segundo ele, são as festas aos orixás, além de várias ações sociais que o Terreiro desenvolve com crianças e jovens da comunidade, que não têm oportunidade de frequentar a escola no turno integral, e assim vão ao Terreiro no turno oposto à aula para participarem das várias atividades educativas oferecidas pelo llê. O Terreiro também faz, há mais de 20 anos, a lavagem do Beco do Fuxico, uma das mais tradicionais festas da cidade, que consiste na abertura do carnaval de Itabuna.

A educação das crianças do Terreiro é feita conjuntamente com os pais, dentro de suas casas, que acompanham o 
crescimento delas, ampliando a educação familiar. As crianças aprendem com os mais velhos, principalmente por meio da observação. "Aqui temos a nossa própria pedagogia, que é feita através da prática do aprender fazendo", relatou Pai Gildo.

O Babalorixá ainda fez questão de frisar que na cidade de Itabuna também existe preconceito com os adeptos das religiões de matriz africana: "não recebemos nenhum apoio do poder municipal, todos os terreiros são obrigados a pagar IPTU e as igrejas de outras denominações não, não recebemos nada de políticos, nada das organizações governamentais".

A fala do Pai de Santo referente à falta de incentivo governamental para atividades do Terreiro reflete a realidade desse espaço; porém, cabe ressaltar que, há algum tempo, principalmente a partir da década de 2000 , diversas políticas públicas têm sido construídas em âmbito federal, estadual e municipal, embora exista ainda muito a se fortalecer. Projetos de apoio às comunidades tradicionais foram criadas e publicizadas por meio de editais públicos, inclusive com ministério e secretarias estaduais e municipais de promoção da igualdade racial, atendendo à reivindicação e pressão por parte da sociedade organizada.

Sobre o racismo, Pai Gildo observa que as pessoas de terreiro quando saem nas ruas da cidade (Itabuna) vestidas de roupas de orixás são discriminadas. "Aqui na cidade, é difícil encontrar uma baiana vendendo acarajé, pois se estiver trajada com suas vestimentas próprias ninguém compra, eu mesmo já fui chamado de macumbeiro e feiticeiro várias vezes nas ruas da cidade", enfatiza Pai Gildo. 
Quando perguntado sobre a discriminação a crianças e jovens do Terreiro, especialmente nas escolas, ele disse que elas "chegam aqui várias vezes se queixando de muitos atos de racismo religioso nas suas escolas, até mesmo os professores discriminando elas". As crianças de terreiro, de acordo com o Babalorixá, perdem suas amizades da escola e muitas terminam deixando a instituição. Pai Gildo relata: “já acolhi algumas crianças que passaram o ano aqui por não quererem ir mais para a escola, muitos dos Pais de Santos de Itabuna chegam a evitar sair de casa por causa da perseguição proveniente do racismo sofrido".

\section{BABÁ PECÊ - SALVADOR (Figura 23)}

Em 1991, Babá Pecê, Sivanilton Encarnação da Mata, filho biológico de Mãe Nizete, assume o Terreiro, contando com apoio das anciãs da Casa de Oxumarê, que tanto aguardavam a profecia de Ogum em seu nascimento. Babá Pecê nasceu no terreiro de Oxumarê, no dia da sua celebração. Babá Pecê, com seu amor e carisma, tornou-se uma referência de conduta sacerdotal por todo o território nacional e internacional. O reconhecimento de Babá Pecê no âmbito religioso e político veio de todo o trabalho por ele desempenhado para a promoção e defesa não só do povo de santo, mas também por proteger a infância, a comunidade negra e aqueles em situação de maior vulnerabilidade. Até hoje, Babá Pecê tem o comando da casa e foi com ele que começamos as entrevistas sobre a questão do racismo religioso.

O Babalorixá da Casa de Oxumarê foi categórico ao afirmar que para ele uma das piores coisas por que passam 


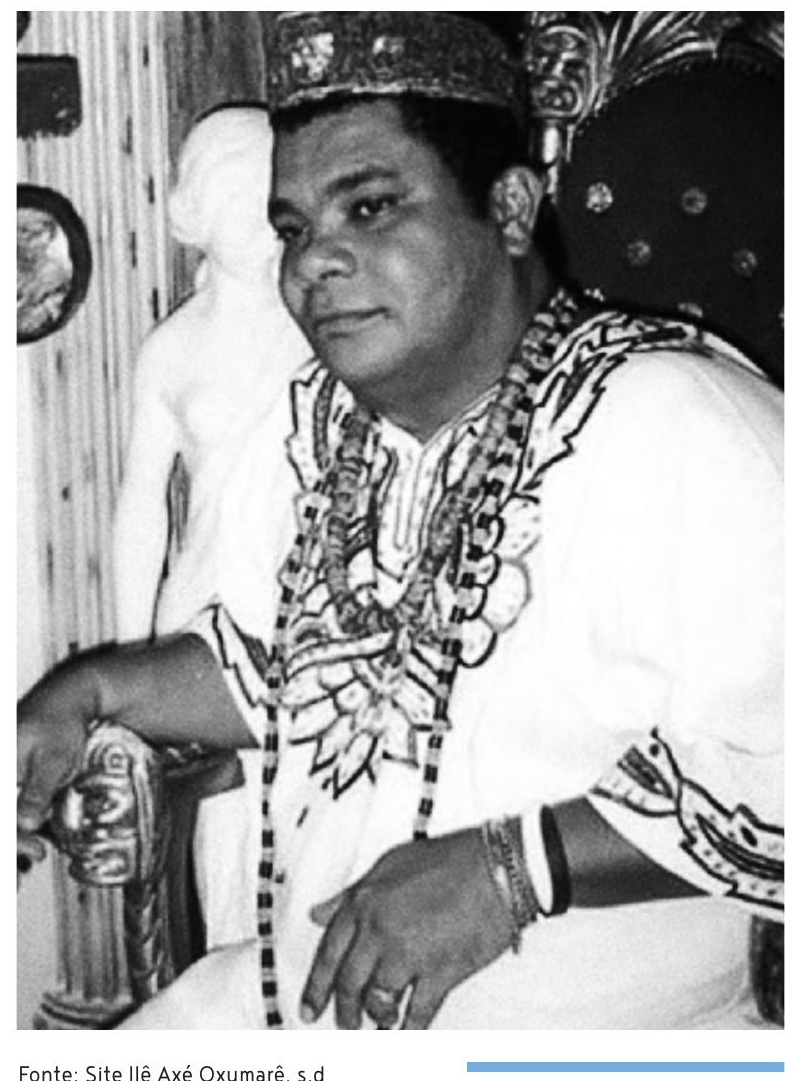

Fonte: Site llê Axé Oxumarê, s.d

as religiões de matriz africana é o racismo religioso. Afirmou que, durante todo esse tempo de sacerdócio, acompanha de perto os atos de discriminação, perseguição e racismo contra o povo de santo cotidianamente. Para ele, os ataques, principalmente promovidos pelas igrejas pentecostais, são os mais frequentes, tendo relatado que já presenciou ações violentas contra as religiões de matriz africana, tanto na sua Casa, quanto em inúmeras outras localizadas em Salvador e também no interior do estado. Por causa disso, Babá

Figura 23

Babá Pecê de Oxumarê saudando os Orixás. 
Pecê, por ser uma liderança religiosa de um dos mais antigos terreiros de Salvador - llê Axé Oxumarê, que também era membro do Coletivo de Entidades Negras, sempre esteve à frente de todas as ações e manifestações em defesa da liberdade religiosa do povo de santo.

Foi ele quem liderou um grande movimento pela manutenção de uma árvore sagrada, localizada dento da área do Oxumarê, onde a prefeitura desejava construir uma passarela para travessia de pedestres, o que iria interferir profundamente nos aspectos físicos, morais e religioso da instituição. A luta e mobilização foi intensa, culminando com a mudança do local da construção da passarela e a preservação do espaço sagrado do Terreiro.

Outro caso de racismo religioso relatado por Babá Pecê, e já referido neste trabalho, foi o ocorrido no Terreiro de Mãe Rosa - llê Axé Oyá Onipó Neto, que acabou por ter parte do espaço demolida pela prefeitura de Salvador. Embora tenha sido contestada por ação de reintegração de posse pela justiça, a ação da liderança do Babalorixá da Casa de Oxumarê, juntamente com outras instituições do movimento negro e de defesa dos direitos humanos, conseguiu resistir e reverter a situação, por meio de uma intensa e ampla mobilização.

Babá Pecê acredita que o racismo religioso sofrido pelas religiões de matriz africana, especialmente com as crianças e jovens nos espaços escolares, "é fruto de uma grande ignorância, falta de segurança e principalmente falta de fé e respeito ao outro". O Babalorixá afirma também que "sonha em que um dia todos os segmentos religiosos possam desenvolver seu papel de pregadores do amor e entendam 
que todos somos iguais e, portanto, temos que respeitar o desejo e vontade do outro ser de qualquer religião".

Após ouvir os Sacerdotes, autoridade máxima na hierarquia dos Terreiros, passou-se a entrevistar as crianças e jovens, seguindo o roteiro pré-estabelecido (Apêndice), como previsto no projeto de pesquisa.

5.2.2 CRIANÇAS E JOVENS DO ILÊ AXÉ ODARA E ILÊ AXÉ OXUMARÊ

Inicialmente, passa-se a caracterizar o universo de crianças e jovens que participaram diretamente deste estudo. Como pode ser observado no Quadro 2, Na próxima página, foi entrevistado um total de nove crianças e jovens, sendo cinco do Terreiro llê Axé Odara e quatro do llê Axé Oxumarê. Além disso, foram observados, de forma menos sistemática, outros integrantes dos Terreiros com a mesma faixa etária dos pesquisados diretamente.

Na intenção de resguardar os entrevistados, na sua maioria menores de idade, suprimimos seus nomes de batismo e optamos por identificá-los com a palavra Erê, como são chamados os seres espirituais infantis no Candomblé. Para diferenciá-los, associamos a palavra Erê ao nome do orixá de cabeça de cada uma das crianças e dos jovens.

A escolha dessa denominação não foi uma criação pessoal, ela foi inspirada na dissertação de mestrado da professora Souza (2010), por meio da qual foi usada a expressão Erê para caracterizar as crianças que foram entrevistadas. 


\section{Quadro 2 - Caracterização das crianças e jovens entrevis-}

tados, ano de referência - 2018.

\begin{tabular}{|c|c|c|c|c|c|c|}
\hline & $\begin{array}{c}\text { NOME ADOTADO } \\
\text { NA PESQUISA }\end{array}$ & $\mathrm{COR}^{*}$ & SEXO & IDADE & ANO & INSTITUIÇÃO \\
\hline \multirow{5}{*}{$\begin{array}{l}\text { ILÊ AXÉ } \\
\text { ODARA }\end{array}$} & Erê de lansã & Negra & $\mathrm{F}$ & 17 & $9^{\circ}$ & Pública \\
\hline & Erê de Yemanjá & Parda & $\mathrm{F}$ & 17 & $9^{\circ}$ & Pública \\
\hline & Erê de Obaluayê & Branco & M & 08 & $3^{\circ}$ & Privada \\
\hline & Erê de Oxum 1 & Negra & $\mathrm{F}$ & 18 & $3^{\circ}$ & Pública \\
\hline & Erê de Xangô & Negra & $\mathrm{F}$ & 09 & $2^{\circ}$ & Pública \\
\hline \multirow{4}{*}{$\begin{array}{r}\text { ILÊE AXÉ } \\
\text { OXUMARÉ }\end{array}$} & Erê de Oxum 2 & Negra & $\mathrm{F}$ & 13 & $7^{\circ}$ & Pública \\
\hline & Erê de Nanã & Negro & M & 10 & $5^{\circ}$ & Privada \\
\hline & Erê de Oxumarê & Negra & $\mathrm{F}$ & 12 & $7^{\circ}$ & Público \\
\hline & Erê de Ayrá & Negro & M & 18 & $3^{\circ}$ & Pública \\
\hline
\end{tabular}

Fonte: Dados do pesquisador. 
A pesquisa direta ocorreu no período de março de 2018 a fevereiro de 2019, sendo as entrevistas realizadas nos meses de setembro de 2018 a janeiro de 2019. Segue abaixo a caracterização dos entrevistados (Quadro 2).

Passaremos agora à análise do perfil dos Erês entrevistados pelo processo de autoidentificação. Conforme observa-se no Quadro 2, ao lado, sete dos nove entrevistados se autodeclararam como negros, um como pardo e um como branco. Essa predominância se mostra coerente com o fato de se tratar de um espaço religioso de matriz africana, cuja origem histórica é de pessoas que aportaram no Brasil por meio do processo de diáspora.

Das crianças e jovens, as do sexo feminino são maioria entre os entrevistados em ambos os Terreiros (seis dos nove no total). Embora essa escolha não tenha sido direcionada, a convivência nesses espaços possibilitou perceber uma maior disposição destas ao serem informadas do que se tratava a pesquisa, pois elas sofrem mais racismo religioso, pelo que tem sido observado, do que os do sexo masculino. A faixa etária dos pesquisados está entre 8 e 18 anos, na época das entrevistas, sendo coerente com a escolaridade. Predomina a frequência às escolas públicas, observando-se que apenas dois deles estudam em escolas da rede privada de ensino (os de menor idade), o que mostra que as crianças e jovens desses Terreiros residem em regiões periféricas, normalmente no entorno desses espaços. 


\section{ERÊ DE IANSÃ}

Erê de lansã é uma jovem de 17 anos, considera-se negra, reside na cidade de Itabuna, estuda no Instituto Municipal Aziz Maron, no turno noturno, cursando o $9^{\circ}$ ano do Ensino Fundamental e na sua escola não tem aula de religião. Há seis anos ela frequenta o Terreiro e está passando por processo de iniciação no Candomblé para "fazer o seu santo", ou seja, ser consagrada ao Orixá "dono do seu Ori" (cabeça). Seus pais e avós são também frequentadores do Terreiro.

Assume-se como candomblezeira e, embora ainda não tenha uma função específica no llê, faz tudo que se pede: varre a casa, lava os pratos e arruma o barracão. Entende o terreiro como um espaço de educação e considera o aprendizado do espaço melhor que o da escola, pois "o Pai de Santo fala da África e dos ensinamentos dos ancestrais, ensina como se comportar na vida, pedindo licença, respeitando os mais velhos e aprendendo através da observação e do cuidado que o Babalorixá tem a ensinar". Ou seja, prefere o Terreiro à escola.

Todas as colegas da escola sabem que ela é do Candomblé, ela mesma contou no bate-papo. Os professores também sabem porque ela mesma falou, e sempre se coloca a favor do Candomblé em discussões na escola. No turno noturno não percebeu nenhum ato de racismo religioso contra ela. Relatou, também, que adora ser do Candomblé; vai de branco para a escola quando está em período de obrigação e nunca sofreu preconceito, sempre se assumiu, porém, apesar disso, disse que já escutou "brincadeiras de mau gosto em relação ao Candomblé", mas isso não a abalou. 
"Já fui chamada de macumbeira e fazedora de coisa ruim, mas não liguei”.

Fica claro que apesar de Erê lansã não ter se sentido ofendida ou até não perceber a gravidade dos acontecimentos, não podemos desprezar o que foi relatado por ela ao dizer que algumas vezes "foram feitas brincadeiras pejorativas em relação a sua religião". Levar essas ofensas como forma de brincadeira é uma das maneiras que o racismo tem de esconder a realidade que passa o povo negro e religiosos de matriz africana deste país, tal prática não deixa de ser um mecanismo de tentar diminuir e descaracterizar o racismo religioso tão presente no Brasil.

\section{ERÊ DE IEMANJÁ}

22. Rituais religiosos das religiões de matriz africana onde normalmente os participantes se desfazem de um bem material em homenagem a um orixá ou entidade espiritual. Limpeza de uma pessoa de uma casa, de uma família.

Erê de lemanjá é uma jovem de 17 anos, identifica-se com a cor parda e se define como alguém que não é negra nem branca. Ela estuda no Colégio Estadual Sesquicentenário (CISO) onde cursa o $9^{\circ}$ ano. Há quatro anos ela estuda na mesma escola e nunca teve aula de religião, "no CISO nem se fala em religião". Declara-se candomblezeira, frequenta o Terreiro desde criança e há um ano é consagrada ao Orixá lemanjá. Durante todo o processo de pesquisa no Terreiro, esta Erê de lemanjá estava na Casa, próxima e cuidando dos afazeres e do Pai de Santo. Os ensinamentos do terreiro para ela são fundamentais, pois ensinam a fazer as comidas, conhecer as folhas e suas utilidades, preparar os "banhos de folha", arrumar os Ebós ${ }^{22}$. Relatou que "no terreiro se aprende ensinando ou observando o Pai e as mais velhas, enxerga o terreiro como uma escola, pois, ajuda na 
convivência fora do terreiro". Para ela existem duas pedagogias: a formal e a do cotidiano no Terreiro.

Todos os colegas sabem da sua religião, ela mesma contou, pois no período da "obrigação" teve que ir vestida de branco e com os aparatos do processo de iniciação no Candomblé, a "feitura". A professora e diretora descobriram por causa de uma grande briga com uma colega que a discriminou e ofendeu por causa da sua religião. A escola teve uma postura séria de combate ao acontecido e evitou outros problemas. Porém, a Erê de lemanjá relatou que, caso continuasse sofrendo racismo, deixaria de frequentar a escola. Isso reforça a ideia de que racismo religioso é um dos motivos das altas estatísticas de evasão escolar verificadas.

A entrevistada também relatou que nunca levou ninguém da escola para o Candomblé e que na escola tem muitos colegas evangélicos que a maltratam e a ofendem, principalmente quando está em "obrigação", já que nesse período ela não vai para a escola de farda, e sim de roupa de terreiro, já que a instituição permite. Porém, as ofensas são recorrentes: "lá vem a macumbeira, lá vem a feiticeira". Ela nunca escondeu sua identidade religiosa, mesmo sofrendo o preconceito.

\section{ERÊ DE OBALUAYÊ}

Erê de Obaluayê tem oito anos e frequenta o Terreiro desde o dia em que nasceu. Ele se identifica como alguém que possui pele branca, estuda na escola Cristão Filhos do Rei, onde cursa $03^{\circ}$ ano do Ensino Fundamental I. Algumas vezes tem aula de religião na escola, mas ele não participa, 
porém, é obrigado a participar das festas. A instituição que o entrevistado estuda é privada e evangélica, sempre acontece nas festas a presença de grupos musicais cantando canções religiosas e todos são obrigados a participar.

Ele frequenta o Candomblé há oito anos, a mãe frequenta o Candomblé às vezes e o pai é o primeiro Ogã da casa. No Terreiro ele aprende a respeitar os mais velhos e - Orixá, a tocar os atabaques, falar outra língua (Bantu), e sempre observar o que os mais velhos estão fazendo.

Os colegas de sala não sabem que ele é do Candomblé, porque, como ele disse, "se eu falar vão me chamar de macumbeiro", "zombarem" de mim, "se eu falar vão rir de minha cara e falar muitas coisas ruins". Os professores e funcionários da escola também não sabem que ele é do Candomblé, pois ele esconde sua religião, bem como sua melhor amiga na escola, que também pertence à mesma religião. Ele esconde sua prática religiosa na escola para não sofrer perseguição, pois uma colega e amiga sua se expôs, aparecendo na escola com as roupas brancas e contas no pescoço, foi maltratada e sofreu muita discriminação, ficando, então, vários dias sem ir à escola porque estava com medo e vergonha, medo de apanhar e vergonha de ser do Candomblé. O entrevistado gosta de ser do Candomblé e vai enfrentar as pessoas que falem mal da sua religião.

\section{ERÊ DE OXUM 1}

Erê de Oxum tem 18 anos e concluiu o terceiro ano do Ensino Médio no Colégio Estadual Felix Mendonça, na cidade de Itabuna. Ela identificou-se, a princípio, como de 
cor parda, mas após algumas perguntas se colocou como negra. Na sua escola não tem aula de religião, porém nas aulas de história se falava do tema, inclusive, sobre o Candomblé. Ela se diz católica e do Candomblé, pois, além de vir no terreiro, vai à igreja católica. Quando está em um espaço fora do Candomblé, inclusive na escola, diz ser adepta da outra religião.

A entrevistada frequenta o Terreiro há cerca de quatro anos, está em processo de iniciação, já participa de quase todos os rituais religiosos da Casa e logo estará sendo iniciada como Yaô. Os pais dela são do Candomblé, mas os irmãos não frequentam esse espaço religioso. Ela reconhece - Terreiro como uma verdadeira escola para a vida, pois lá aprende os afazeres práticos e os valores éticos e morais, como a construção do sentimento de igualdade, de respeito às diferenças de raça e credo. Terminou o Ensino Médio escondendo a sua condição de candomblezeira, e quando alguém pergunta sobre sua religião, declara-se católica. Ela verbalizou:

Vejo o Terreiro como um lugar que me ensina a ser uma pessoa melhor, saio daqui sabendo que devo ajudar as pessoas e respeitar ao próximo, não discriminar nem por religião, nem por sua cor. Na escola ninguém sabia que eu era do candomblé, não queria ser zoada, eu escondia minha condição, já presenciei uma colega sofrer uma grande discriminação e isso fez ela se afastar da escola, então não me apresentava de candomblé. Queria que essa cidade me enxergasse como uma pessoa normal, me sinto abalada psicologicamente, nem professores nem diretores da escola sabiam que eu era do candomblé. Muita vontade de defender, ninguém da escola veio conhecer o terreiro, eu me sinto feliz no terreiro, uma pessoa mais alegre, adoro meus irmãos do terreiro, somos 
23. Palavra de origem

Yorubá que designa os filhos de santos no candomblé já iniciados, mas que ainda não completaram o período de sete anos da iniciação. uma verdadeira família. Não consigo usar roupa de candomblé na rua, só quando vamos a atividades coletivas e todas se vestem de baianas, aí nos sentimos protegidas. Só após os sete anos uma Yaô se tornará uma Egbome ${ }^{23}$ (Erê de Oxum 1, 2018).

Como relatou, Erê de Oxum 1 presenciou uma colega bem próxima sofrer uma agressão verbal muito grave devido a ida à escola usando roupas brancas e contas, portanto ela optou por se esconder. De acordo com ela, "isso foi muito ruim", pois sabia que, se alguém descobrisse, ela seria maltratada. Relatou ainda que, quando estava na escola, se sentia outra pessoa, era triste e afastada das colegas, não tinha alegria porque não podia ser quem ela era, só se sentia feliz, satisfeita e completa quando estava no Terreiro.

\section{ERÊ DE XANGÔ}

Erê de Xangô tem nove anos de idade e está cursando - $2^{\circ}$ ano do Ensino Fundamental I na Escola Municipal Everaldo Cardoso. Ela se reconhece como negra e, embora frequente o Terreiro há sete anos, não diz na escola que é do Candomblé "para não sofrer bulem [bullying] das colegas", ela acredita que seria "isolada do convívio com as amiguinhas se soubessem que ela frequenta Terreiro".

Na sua escola, às vezes, tem aula de religião, existe uma professora que ministra essas aulas das quais Erê de Xangô participa. Ela contou que o assunto mais falado na aula é sobre Deus, nunca se falou do Candomblé. Ela continua afirmando, na entrevista, que é católica e do Candomblé, disse que toda sua família frequenta a igreja e o terreiro, e quando alguém pergunta na escola qual a sua religião, ela 
diz ser católica. "Eles (os colegas) dizem que candomblezeira é macumbeiro e abusam, zoam".

No Candomblé ela gosta de dançar, ver os Orixás e brincar com os Erês. Além de aprender a dançar, também é orientada a respeitar a natureza e se sente muito feliz no Terreiro. Na escola, "quando falam mal do Candomblé, eu saio de perto e vou para outo lugar, fico isolada". Nem os colegas nem a direção ou professores e coordenação sabem que ela pertence ao Candomblé. Ela acredita que, se soubessem, teria que pedir à mãe para sair da escola, porque não ia aguentar, pois, "mesmo gostando (do Candomblé), não tenho coragem de dizer, já presenciei em outra sala um colega ser tratada mal na hora do recreio, muitos iam atrás dele abusando e chamando de macumbeiro, ele teve que sair da escola".

5.2.4 CRIANÇAS E JOVENS DO ILÊ AXÉ OXUMARÊ

Neste terreiro foram entrevistadas quatro crianças ou jovens entre 6 e 18 anos, cujos resultados estão apresentados individualmente a seguir,

\section{ERÊ DE OXUM 2}

Erê de Oxum 2 tem 13 anos de idade, considera-se negra, estuda na Escola Estadual Maria Romana Calmon, está cursando $\circ 7^{\circ}$ ano do Ensino Fundamental II e questiona a qualidade do ensino da instituição. Na escola não tem aula de religião e não se discute a temática. A entrevistada 


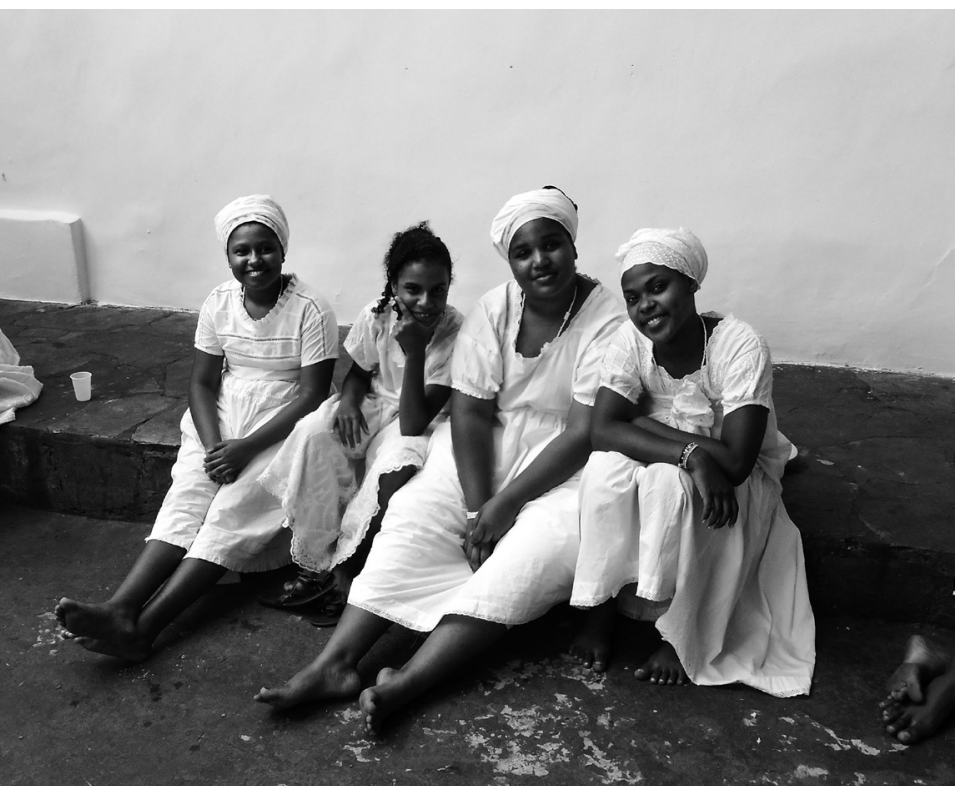

Fonte: dados do pesquisador

Figura 25

Crianças e jovens do Terreiro llê Axé

Oxumarê.

declarou-se religiosa de matriz africana desde o seu nascimento, disse que já nasceu no Candomblé, foi iniciada para o Orixá Oxum com apenas dois anos de idade e seus pais também são do Candomblé. Quando perguntada como aprendia as coisas no Candomblé e se via o terreiro como um espaço de educação, ela respondeu de forma muito segura:

Na verdade, eu nem sei como isso acontece, pois eu já nasci aprendendo, desde que era bem pequena eu vinha para o terreiro e ficava olhando, observando e repetindo as coisas feitas pelos mais velhos, sinto que todo este aprendizado que tenho neste espaço é bem diferente dos ensinamentos da escola, aqui eu aprendo a ser mais humilde, respeitar mais as outras pessoas, compreender 
o que os mais velhos me ensinam, na verdade o candomblé me faz uma pessoa muito feliz e respeitadora (Erê de Oxum 2, 2018).

Na escola ninguém sabia que ela era do Candomblé, nem as colegas, nem os professores, nem a direção, ela nunca falou porque sentia receio de se expor, mesmo depois de iniciada, respondia que frequentava algumas vezes e se dizia católica.

Quando a entrevistada fez as "obrigações de sete anos" do Candomblé e teve que ir para a escola usando roupas brancas e elementos religiosos que a identificavam como uma adolescente de Terreiro, foi isolada pelos colegas que olhavam para ela com "rosto de nojo e desrespeito", tendo sido chamada de macumbeira. Dessa forma, foi afastada das atividades, passou a se distanciar ainda mais e sofrer muito. Ela contou que o seu "sofrimento abalou profundamente a mãe, que não entendia o que estava acontecendo, porque ela chorava tanto ao retornar da escola e sentia-se muito deprimida, tendo vontade até de abandoná-la", relatou, ainda, que o pior foi assistir ao sofrimento da sua mãe, que ficava muito triste em ver a filha naquela situação.

Erê de Oxum 2 contou que a situação só melhorou um pouco quando ela identificou na sala de aula dois colegas que também eram do Candomblé, tendo se unido a eles e, juntos, tiveram força para reagir às discriminações que sofriam. Outro fato que a fortaleceu foi contar a sua mãe o que acontecia, daí esta foi à instituição e conversou com os gestores, tendo eles passado a interferir, por meio de ações esclarecedoras, sobre a situação de racismo religioso pela 
qual estava passando a aluna, junto aos alunos e professores, amenizando estes atos.

Ao final da conversa, a entrevistada disse que apesar de tudo que aconteceu, pelo Candomblé, enfrentaria tudo novamente. Para ela, a sua religião "é tudo na vida, é onde aprendo, ensino, estudo e me torno uma pessoa melhor para mim e para os outros, todos os dias".

\section{ERÊ DE NANÃ}

Erê de Nanã tem apenas 10 anos de idade, declara-se negro, estuda no Colégio Nabuco, escola da rede particular, e cursa o quinto ano do Ensino Fundamental I. Na sua escola não tem aula de religião na grade curricular e pouco se fala sobre o tema.

Com apenas dois anos de idade ele foi suspenso a Ogã, pelo Orixá Nanã da Egbome Jéssica. Com muita firmeza ele afirma ser do Candomblé, disse que já nasceu no terreiro e é sobrinho do Pai de Santo. Seus pais também são do Candomblé, sendo o pai Ogã e a mãe Egbome. Descreve com detalhes a importância da educação que recebe no Terreiro para sua formação na vida com os ensinamentos da religião que, segundo ele, são aprendidos por meio da sua observação e também das ações práticas, como pegar uma folha sagrada, cuidar dos atabaques, limpar os Santos, varrer o Terreiro, limpar os bichos. Ele relata que recebe diariamente ensinamentos que vão formando sua personalidade. 
Erê de Nanã demorou muito de se apresentar na escola como religioso de matriz africana, apesar dos diretores da escola serem do Candomblé. Porém, ele declarou que

\begin{abstract}
Na sala tinha muitos alunos evangélicos que falavam o tempo todo mal da minha religião e eu ficava com vergonha de falar, pois sabia que sofreria racismo, mas este ano eu resolvi assumir, no meio da aula, pedi a palavra à professora e disse em voz bem alta "eu sou do terreiro Oxumarê, sou suspenso a Ogã e o candomblé não é isso que vocês estão falando, se quiserem saber mais vamos a uma festa de Santo". A partir deste dia me senti aliviado, não precisava mais fingir que era católico, apesar de durante um período ter sido bastante desprezado pelos colegas, me senti aliviado por poder assumir minha condição religiosa. (Erê de Nanã, 2018).
\end{abstract}

Ele disse que, depois do seu anúncio, pôde questionar as ofensas e dizer para os colegas o que realmente era o Candomblé, tendo sido a sua declaração importante, inclusive, para uma das suas professoras. que também era do Candomblé e nunca teve coragem de assumir. E "com a minha atitude ela sentiu-se fortalecida, e depois deste dia várias vezes passamos a falar sobre a cultura e religião africana". Finalizando, Erê de Nanã disse que o Candomblé é sua vida e que nasceu ali e jamais sairá do terreiro, "é ali que aprendo, até mais do que na escola".

\title{
ERÊ DE OXUMARÊ
}

Erê de Oxumarê tem 12 anos de idade, autodeclara-se preta, estuda na escola municipal Visconde de Cairu e cursa o $7^{\circ}$ ano do Ensino Fundamental II. É Ekede suspensa aos dois anos de idade para o Orixá Oxumarê de Babá Pecê, Pai 
de Santo do terreiro, e é filha da Egbome Viviane de Oxóssi, portanto, praticamente nasceu na Casa de Oxumarê e sempre está no terreiro.

A entrevistada declarou que nunca escondeu a sua religião de ninguém, que colegas, professores e direção sabiam que era do Candomblé e que isso fez com que, durante alguns anos, ela fosse muitas vezes ofendida por todos; sempre que ela chegava para participar das brincadeiras não era bem aceita, e os colegas mandavam ela procurar Jesus porque ela tinha "parte" com o diabo.

Erê de Oxumarê teve uma reação diferente da maioria das crianças e jovens discriminados por causa da sua religião, pois, enquanto a maioria ficava calada e sofria muito internamente, ela partiu para o enfrentamento, apresentando um bom nível de conhecimento dos fundamentos da religião, assim ela enfrentava a todos, argumentando e mostrando que Candomblé não é nada daquilo que eles estavam falando, pedia respeito e dizia que "cada um tem o direito de seguir a religião que escolher".

Ao final, ela disse que considera terreiro de Candomblé um lugar de muitos ensinamentos, onde ela aprende muitas coisas importantes para sua vida, principalmente cuidar das folhas, já que, de acordo com ela, "sem folha não existe Candomblé, sem folha não existe vida, não existe nada".

Apesar de assumir e enfrentar ser do Candomblé, ela não deixou de sofrer o racismo religioso na escola por vários anos, porém, encontrou uma forma de reagir, utilizando os conhecimentos adquiridos no próprio Terreiro. 


\section{ERÊ DE AYRÁ}

Erê de Ayrá tem 18 anos de idade, autodeclarou-se negro e estuda no Colégio Estadual Duque de Caxias, cursando o terceiro ano do Ensino Médio. O que mais gosta da escola é a educação que é passada, diz que seus professores são muito competentes e têm postura de muito respeito com todos.

O entrevistado é Ogã confirmado para o Orixá Airá da Egbome Mariana. Participa do Candomblé desde que nasceu e tem cargo de Oloiêê24, aquele que faz tudo no Candomblé: cuida dos bichos; toca atabaques; cuida do salão; da comida e o que mais precisar. A mãe também é do Candomblé e o pai não tem religião. Ele descreveu, de forma muito amadurecida, a importância de tudo que aprende no Terreiro, sendo que, para ele, os 18 anos de convivência com a família Oxumarê fez com que aprendesse a ter uma postura muito séria e respeitosa com todos, afirmou ter sido "uma escola para a vida".

Erê de Ayrá disse que em nenhum momento da sua vida escolar se sentiu discriminado por causa da sua religião e, de acordo com ele, a sua postura de seriedade e respeito com os outros e todo seu conhecimento sobre os conceitos e práticas do Candomblé não permitiram que isso acontecesse. Ele sabe que na sua escola outros colegas sofreram esse tipo de racismo, mas ele, em particular, em nenhum momento passou por uma situação semelhante.

Como quase todos os entrevistados, ele relatou a alegria e felicidade que sente em ser do Candomblé, informou que o terreiro é a sua maior escola e que não pretende deixar 
a sua religião nunca. Pelo contrário, pretende ser um grande propagador desses fundamentos para que cada dia menos pessoas sofram o racismo religioso por serem do Candomblé.

\subsection{O QUE DIZEM AS CRIANÇAS CANDOMBLECISTAS}

Após a transcrição e análise das entrevistas individuais, refletiu-se sobre os principais resultados alcançados a partir das questões que foram abordadas em todas as entrevistas e, apesar de não se tratar de pesquisa quantitativa, elaborou-se um quadro síntese para melhor visualização desses resultados, disponíveis a seguir.

Os quadros 3 A e 3 B sintetizam os resultados das entrevistas qualitativas realizadas nos Terreiros llê Axé Odara e llê Axé Oxumarê; dessa forma, constata-se que, entre os pesquisados, quatro estão acima dos 15 anos, dois entre 11 e 15 anos e três com até 10 anos de idade. Sete deles frequentam o terreiro desde criança, sendo que seis desde que nasceram, e apenas três dos entrevistados conheceram - Candomblé após os 10 anos de idade.

Dos nove entrevistados, cinco declararam que se assumem, na escola, como religiosos de matriz africana, e quatro escondem a sua condição de candomblezeira. Somente o Erê de Aira, entre os cinco entrevistados que se declararam religiosos de matriz africana, afirma que nunca sofreu racismo religioso na escola, de acordo com ele, devido a sua postura de respeito com todos os colegas. Além de muita segurança ao falar sobre sua religião, porém, já presenciou outros colegas da escola serem discriminados. Os quatro 


\section{Quadro 3 A - Síntese das entrevistas qualitativas, TERREIRO ILÊ AXÉ ODARA.}

\begin{tabular}{|c|c|c|c|c|c|}
\hline $\begin{array}{l}\text { NOME } \\
\text { ADOTADO NA } \\
\text { PESQUISA }\end{array}$ & $\begin{array}{l}\text { IDADE } \\
\text { (ANOS) }\end{array}$ & $\begin{array}{l}\text { TEMPO NO } \\
\text { CANDOMBLÉ } \\
\text { (ANOS) }\end{array}$ & $\begin{array}{l}\text { ASSUME SUA } \\
\text { RELIGIÃO NA } \\
\text { ESCOLA }\end{array}$ & $\begin{array}{c}\text { DECLAROU QUE SOFREU RACISMO } \\
\text { RELIGIOSO }\end{array}$ & $\begin{array}{c}\text { RECONHECEU O TERREIRO COMO } \\
\text { ESPAÇO DE EDUCAÇÃO }\end{array}$ \\
\hline Erê de lansã & 17 & 06 & SIM & $\begin{array}{l}\text { "Já fui chamada de macumbeira } \\
\text { e fazedora de coisa ruim, mas não } \\
\text { liguei". } \\
\text { Declarou que foram feitas } \\
\text { brincadeiras pejorativas em relação } \\
\text { a sua religião. Levar estas ofensas } \\
\text { como forma de brincadeira é uma } \\
\text { das formas que o racismo tem de } \\
\text { esconder a realidade que passa o } \\
\text { povo negro e religiosos de matriz } \\
\text { africana. }\end{array}$ & $\begin{array}{l}\text { "Pai de Santo fala da África e dos } \\
\text { ensinamentos dos ancestrais, ensina } \\
\text { como se comportar na vida, pedindo } \\
\text { licença, respeitando os mais velhos } \\
\text { e aprendendo através da observação } \\
\text { e do cuidado que o Babalorixá tem a } \\
\text { ensinar". }\end{array}$ \\
\hline $\begin{array}{l}\text { Erê de } \\
\text { Yemanjá }\end{array}$ & 17 & 17 & SIM & $\begin{array}{l}\text { A maltratam e a ofendem, } \\
\text { principalmente quando está em } \\
\text { "obrigação", já que nesse período } \\
\text { ela não vai para a escola de farda, } \\
\text { e sim de roupa de terreiro, já } \\
\text { que a escola permite, porém, as } \\
\text { ofensas são recorrentes: “lá vem a } \\
\text { macumbeira, lá vem a feiticeira”. }\end{array}$ & $\begin{array}{l}\text { "No terreiro se aprende ensinando ou } \\
\text { observando o Pai e as mais velhas, o } \\
\text { terreiro é uma escola, pois, ajuda na } \\
\text { convivência fora do terreiro". Existem } \\
\text { duas pedagogias: a formal e a do } \\
\text { cotidiano no Terreiro. }\end{array}$ \\
\hline $\begin{array}{c}\text { Erê de } \\
\text { Obaluayê }\end{array}$ & 08 & 08 & NÃO & $\begin{array}{l}\text { "Se eu falar vão me chamar de } \\
\text { macumbeiro", "zombarem", "se eu } \\
\text { falar vão rir de minha cara e falar } \\
\text { muitos coisas ruins". }\end{array}$ & $\begin{array}{l}\text { No Terreiro ele aprende a "respeitar } \\
\text { os mais velhos, a respeitar o Orixá, a } \\
\text { tocar os atabaques, falar outra língua } \\
\text { (Bantu), e sempre observar o que os } \\
\text { mais velhos estão fazendo". }\end{array}$ \\
\hline $\begin{array}{l}\text { Erê de } \\
\text { Oxum } 1\end{array}$ & 18 & 04 & NÃO & $\begin{array}{l}\text { “[...] não queria ser zoada, eu } \\
\text { escondia minha condição, já } \\
\text { presenciei uma colega sofrer uma } \\
\text { grande discriminação que fez ela } \\
\text { se afastar da escola, então não me } \\
\text { apresentava de candomblé. Queria } \\
\text { que essa cidade me enxergasse } \\
\text { como uma pessoa normal, me sinto } \\
\text { abalada psicologicamente [...]”. }\end{array}$ & $\begin{array}{l}\text { "Vejo o terreiro como um lugar que } \\
\text { me ensina a ser uma pessoa melhor, } \\
\text { saio daqui sabendo que devo ajudar } \\
\text { as pessoas e respeitar ao próximo, não } \\
\text { discriminar nem por religião nem por } \\
\text { sua cor. } \\
\text { Relatou que, quando estava na escola, se } \\
\text { sentia outra pessoa, era triste e afastada } \\
\text { das colegas, não tinha alegria porque não } \\
\text { podia ser quem ela era, só se sentia "feliz, } \\
\text { satisfeita e completa quando estava no } \\
\text { ambiente do Terreiro". }\end{array}$ \\
\hline $\begin{array}{l}\text { Erê de } \\
\text { Xangô }\end{array}$ & 09 & 07 & NÃO & $\begin{array}{l}\text { Declarou que uma amiga já sofreu } \\
\text { muito por ter sido identificada como } \\
\text { adepta do candomblé. }\end{array}$ & $\begin{array}{l}\text { No candomblé ela gosta de dançar, } \\
\text { ver os Orixás e brincar com os Erês. } \\
\text { Além de aprender a dançar, também } \\
\text { é orientada a respeitar a natureza, } \\
\text { dessa forma, se sente muito feliz no } \\
\text { Terreiro. }\end{array}$ \\
\hline
\end{tabular}

Fonte: Dados do pesquisador. 


\section{Quadro 3 B - Síntese das entrevistas qualitativas. TERREIRO ILÊ AXÉ OXUMARÉ}

\begin{tabular}{|c|c|c|c|c|c|}
\hline $\begin{array}{c}\text { NOME } \\
\text { ADOTADO NA } \\
\text { PESQUISA }\end{array}$ & $\begin{array}{l}\text { IDADE } \\
\text { (ANOS) }\end{array}$ & $\begin{array}{l}\text { TEMPO NO } \\
\text { CANDOMBLÉ } \\
\text { (ANOS) }\end{array}$ & $\begin{array}{l}\text { ASSUME SUA } \\
\text { RELIGIÃONA } \\
\text { ESCOLA }\end{array}$ & $\begin{array}{c}\text { DECLAROU QUE SOFREU RACISMO } \\
\text { RELIGIOSO }\end{array}$ & $\begin{array}{c}\text { RECONHECEU O TERREIRO COMO } \\
\text { ESPAÇO DE EDUCAÇÃO }\end{array}$ \\
\hline $\begin{array}{l}\text { Erê de } \\
\text { Oxum } 2\end{array}$ & 13 & 13 & NÃO & $\begin{array}{l}\text { Quando fez as "obrigações de sete anos" } \\
\text { do candomblé e teve que ir para a escola } \\
\text { usando roupas brancas e elementos } \\
\text { religiosos que a identificavam como de } \\
\text { Terreiro, foi isolada pelos colegas que } \\
\text { olhavam para ela com "rosto de nojo e } \\
\text { desrespeito", tendo sido chamada de } \\
\text { macumbeira [...]. O sofrimento abalou } \\
\text { profundamente a mãe que não entendia } \\
\text { o que estava acontecendo porque ela } \\
\text { chorava tanto ao retornar da escola e } \\
\text { sentia-se muito deprimida, tendo vontade } \\
\text { até de abandoná-la. }\end{array}$ & $\begin{array}{l}\text { "[...] eu vinha para ao terreiro e ficava } \\
\text { olhando, observando e repetindo as coisas } \\
\text { feitas pelos mais velhos, sinto que todo } \\
\text { este aprendizado que tenho neste espaço é } \\
\text { bem diferente dos ensinamentos da escola, } \\
\text { [...] minha religião é tudo na vida, é onde } \\
\text { aprendo, ensino, estudo e me torno uma } \\
\text { pessoa melhor para mim e para os outros, } \\
\text { todos os dias". }\end{array}$ \\
\hline Erê de Nanã & 10 & 10 & SIM & $\begin{array}{l}\text { "Na sala tinha muitos alunos } \\
\text { evangélicos que falavam o tempo } \\
\text { todo mal da minha religião e eu ficava } \\
\text { com vergonha de falar, pois sabia que } \\
\text { sofreria racismo, mas este ano eu resolvi } \\
\text { assumir, [...]". Ele disse que depois do } \\
\text { seu anúncio pôde questionar as ofensas } \\
\text { e dizer para os colegas o que realmente } \\
\text { era o candomblé, tendo sido a sua } \\
\text { declaração importante, inclusive para } \\
\text { uma das suas professoras que também } \\
\text { é do candomblé e nunca teve coragem } \\
\text { de assumir e "com a minha atitude ela } \\
\text { sentiu-se fortalecida e depois deste dia } \\
\text { várias vezes passamos a falar sobre a } \\
\text { cultura e religião africana". }\end{array}$ & $\begin{array}{l}\text { Descreve com detalhes a importância da } \\
\text { educação que recebe no Terreiro para sua } \\
\text { formação na vida, com os ensinamentos da } \\
\text { religião que, segundo ele, são aprendidos } \\
\text { por meio da sua observação e também } \\
\text { das ações práticas como pegar uma folha } \\
\text { sagrada, cuidar dos atabaques, limpar } \\
\text { os Santos, varrer o Terreiro, limpar os } \\
\text { bichos. Ele relata que recebe diariamente } \\
\text { ensinamentos que vão formando sua } \\
\text { personalidade. Disse que o candomblé é } \\
\text { sua vida e que nasceu ali e "jamais sairá } \\
\text { do terreiro, é ali que aprendo, até mais do } \\
\text { que na escola". }\end{array}$ \\
\hline $\begin{array}{l}\text { Erê de } \\
\text { Oxumarê }\end{array}$ & 12 & 12 & SIM & $\begin{array}{l}\text { [...] todos sabiam que era do candomblé } \\
\text { e isto fez com que durante alguns anos } \\
\text { ela fosse muitas vezes ofendida por } \\
\text { todos, sempre que ela chegava para } \\
\text { participar das brincadeiras não era } \\
\text { bem aceita e os colegas mandavam ela } \\
\text { procurar Jesus porque ela tinha "parte" } \\
\text { com o diabo. }\end{array}$ & $\begin{array}{l}\text { No Terreiro ele aprende a "respeitar os } \\
\text { mais velhos, a respeitar o Orixá, a tocar } \\
\text { os atabaques, falar outra língua (Bantu). } \\
\text { e sempre observar o que os mais velhos } \\
\text { estão fazendo". }\end{array}$ \\
\hline Erê de Ayrá & 18 & 18 & SIM & $\begin{array}{l}\text { “[...] não queria ser zoada, eu escondia } \\
\text { minha condição, já presenciei uma } \\
\text { colega sofrer uma grande discriminação } \\
\text { que fez ela se afastar da escola, então } \\
\text { não me apresentava de candomblé. } \\
\text { Queria que essa cidade me enxergasse } \\
\text { como uma pessoa normal, me sinto } \\
\text { abalada psicologicamente [...]”. }\end{array}$ & $\begin{array}{l}\text { "Vejo o terreiro como um lugar que me ensina } \\
\text { a ser uma pessoa melhor, saio daqui sabendo } \\
\text { que devo ajudar as pessoas e respeitar ao } \\
\text { próximo, não discriminar nem por religião } \\
\text { nem por sua cor, } \\
\text { Relatou que quando estava na escola se } \\
\text { sentia outra pessoa, era triste e afastada das } \\
\text { colegas, não tinha alegria porque não podia } \\
\text { ser quem ela era, só se sentia "feliz, satisfeita } \\
\text { e completa quando estava no ambiente do } \\
\text { Terreiro". }\end{array}$ \\
\hline
\end{tabular}

Fonte: Dados do pesquisador. 
entrevistados que não assumiram na escola sua identidade religiosa afirmaram que não o fizeram por medo de serem maltratados pelos colegas, professores e gestores, já que tiveram oportunidade de presenciar outros colegas que são do Candomblé sofrerem racismo religioso e até mesmo abandonarem a escola.

Quando questionados pelo entrevistador sobre a importância do terreiro como espaço de educação, foram unânimes em falar da importância dos ensinamentos e da formação que recebem no terreiro, onde aprendem observando os mais velhos e acompanhando o dia a dia da rotina religiosa. Todos eles enfatizaram que a convivência no terreiro permite o aprendizado de valores éticos e morais, como respeito ao outro, principalmente aos mais velhos, a solidariedade, o respeito e o cuidado com a conservação da natureza, já que, de acordo com todos eles, o Candomblé não existe sem as "folhas".

As entrevistas deixaram bem claro para o pesquisador que as crianças e os jovens dos terreiros entrevistados têm plena convicção de que o terreiro tem sua própria pedagogia, que a forma de aprender nesse espaço religioso é bem diferente da escola. No terreiro, o ensinamento acontece por meio da prática, ao mesmo tempo que aprendemos com os mais velhos ensinamos aos mais novos em um aprendizado coletivo e dinâmico, sendo ao mesmo tempo aluno e professor. 